\title{
Effect of Wheatgrass on DNA Damage, Oxidative Stress Index and Histological Findings in Diabetic Rats
}

\author{
Efecto del Pasto de Trigo sobre el Daño del ADN, el Índice de \\ Estrés Oxidativo y los Hallazgos Histológicos en Ratas Diabéticas
}

Leyla Mis'; Bahat Comba²; Sema Uslu ${ }^{3}$; Aslı Yeltekin ${ }^{4}$

\begin{abstract}
MIS, L.; COMBA, B.; USLU, S. \& YELTEKIN, A. Effect of wheatgrass on DNA damage, oxidative stress index and histological findings in diabetic rats. Int. J. Morphol., 36(4):1235-1240, 2018.

SUMMARY: This study was aimed to search the effect of wheatgrass on the Total Antioxidan (TAS)-Oxidan Status (TOS) and DNA damage in rat with diabetes. The rats used in the study were randomly divided into 4 groups that each of has 10 rats: Control group; $1 \mathrm{ml}$ single dose phosphate-citrate buffer injected i.p ( $\mathrm{pH}: 4.5$ ), Diabetes group; $45 \mathrm{mg} / \mathrm{kg}$ single dose streptozotocin injected i.p., Wheatgrass group; was given oral wheatgrass (10 ml/kg/day) for 6 weeks, Diabetes +Wheatgrass group; $45 \mathrm{mg} / \mathrm{kg}$ single dose streptozotocin injected i.p. and wheatgrass $(10 \mathrm{ml} / \mathrm{kg} /$ day $)$ was given by oral during 6 weeks. After the process of experiment during 6 weeks, blood sample and pancreas tissue were taken. The analysis were done of blood glucose levels, TAS, TOS levels by colorimetric kits; DNA damage by ELISA kits in serum. The pancreas tissues were examined histopathologically. In the group of Diabetes+Wheatgrass was determined that the levels of glucose levels $(\mathrm{p}<0.001)$,TOS $(\mathrm{p}<0.05)$ and OSI $(\mathrm{p}<0.01)$ statistically decreased and heal histopatolojical compared to diabetes group. In the group of Wheatgrass was determined that the levels of TAS $\mathrm{p}<0.05$ statistically increased from other groups. The statistical significance were not found in the level of serum $8 \mathrm{OHdG}$ differences between the groups. The beta cells were seen to increase in the group receiving wheatgrass for therapeutic purposes.As a conclusion, it was determined that wheatgrass strengthened the anti-oxidant defense system and reduced the glucose level in diabetic rats.
\end{abstract}

KEY WORDS: Wheat Grass; Diabetes; DNA damage; TAS; Beta cell.

\section{INDRODUCTION}

Wheatgrass has important effects on human health as it contains most of the required nutrients for humans. It has become one of the important supplemental nutrients for a healthy life (Ashish et al., 2012). Wheatgrass contains high amounts of chlorophyll, vitamins, minerals, amino-acids and enzymes (Rana et al., 2011).

Diabetes mellitus (DM) is a chronic disease, which leads to carbohydrate, fat and protein metabolism disorders. Microvascular, macro-vascular and neuropathic complications may develop in the course of the disease (Akcay \& Akarsu, 2000).

Many researchers have emphasized that this condition leads to macro- and micro-vascular complications of diabetes. Diabetes is an increased oxidative stress status beside metabolic disorders. Increased free radicals may lead to loss of membrane integrity and genetic mutations. The organism possesses anti-oxidant defense systems. The effects of free radicals may be overcome with administration of exogenous anti-oxidants in diabetes (Vincent et al., 2004).

Preservation of DNA integrity and avoidance of developing injury are of great importance for survival. DNA damage may develop in various diseases. $8-\mathrm{OhdG}$ is an indicator of DNA oxidation (Piconi et al., 2003). Streptozotocin (STZ) and alloxan are widely used to induce experimental DM in test animals. STZ is preferred more in laboratory studies as it has more specific beta-cell cytotoxicity (Gorogawa et al., 2002).

The present study was planned to investigate the effect that wheatgrass supplementation has on DNA damage, TAS, TOS and pancreatic tissue in rats with experimentally induced diabetes.

${ }^{1}$ Department of Physiology, Faculty of Veterinary Medicine, Yuzuncu Yil University, Turkey.

${ }^{2}$ Alaca Avni Celık Vocational High School,Hitit Universty,Çorum-Turkey.

${ }^{3}$ Department of Histology and Embryology, Cumhuriyet University, Faculty of Veterinary Medicine, Turkey.

${ }^{4}$ Department of Chemistry, Faculty of Science, Yuzuncu Yil University, Turkey. 


\section{MATERIAL AND METHOD}

In this study were used total of 40 Wistar albino rats weighing between 200 and $250 \mathrm{~g}$ in a climate-controlled animal care facility, with a $12 \mathrm{~h} \mathrm{light/dark} \mathrm{cycle.} \mathrm{They} \mathrm{were}$ divided into 4 groups each containing 10 rats. It was injected ip $0,1 \mathrm{ml}$ a single dose citrate buffer to Control (A) group. Diabetes (C) group and diabetes + Wheatgrass (D)groups a single dose of a freshly prepared solution $(45 \mathrm{mg} / \mathrm{kg}$ of body weight to $0.1 \mathrm{M}$ cold citrate buffer, $\mathrm{pH} 4.5$ ) of STZ were injected i.p. in the rats. After $48 \mathrm{~h}$ blood glucose levels were determined. The animals were considered diabetic if blood glucose values were $>200 \mathrm{mg} / \mathrm{dl}$ the animals were used for diabetic groups. Wheat Grass (B) and Wheatgrass + Diabetes (D) groups were given Wheatgrass extract $(10 \mathrm{ml} / \mathrm{kg} /$ day,) with orally for 6 weeks.

At the end of six weeks, blood and pancreas samples were collected.Blood samples were taken from hearts with sterile injector and placed into tubes with coagulated. Blood glucose levels were determined (eB sensor).The oxidative DNA damage 8- hydroxy-2'-deoxyguanosine (8OHdG) levels were analysis by ELISA kit (Enzo life sciences, USA); TAS, TOS values using a novel automated measurement by colorimetric kits (Rel Assay, Türkiye) in serum. The oxidative stress index (OSI) was calculated with the ratio of TOS to TAS.

Pancreas tissues obtained from all animals in all groups were fixed in $10 \%$ neutral buffered formalin for 24 $48 \mathrm{~h}$. They were blocked in paraffin after routine histological tissue follow-up. Tissue sections of $5 \mu \mathrm{m}$ thickness were placed on polysin-coated slides. Immune-histochemical staining was performed in accordance with the $\mathrm{ABC}$ method (Kanter et al., 2006). The sections were stored in $3 \% \mathrm{H}_{2} \mathrm{O}_{2}$ for $30 \mathrm{~min}$ in order to inhibit peroxidase activity following de-paraffinization and washed with distilled water. Protein block was made in normal goat serum prepared with PBS in $1 / 4$ dilution in order to prevent non-specific binding. The sections were stored in monoclonal insulin protein (180066,Zymed Sanancisco,CA) in 1/40 concentration for one night $\left(4{ }^{\circ} \mathrm{C}\right)$. The sections were washed with PBS for 30 $\mathrm{min}$. Biotin anti-mouse IgG was kept for $30 \times 2 \mathrm{~min}$ and then washed with PBSD. AEC (Aminoethylcarbazole Substrate Kit, Zymed Labaratouries) was kept for $10 \mathrm{~min}$ and washed with tap water. Contrasting staining was carried out with hematoxylin-eosin and sealed with water-based adhesive. Required photos were obtained with Leica ICC 50.

Randomly selected 20 pancreatic islands from each group were examined and beta cells were scored semiquantitatively according to anti-insulin staining, staining severity and density as $(+)$ weak, $(++)$ moderate, $(+++)$ strong, and (++++) very strong (Table II).

The Kruskall-Wallis test was used for comparison of the groups with regard to characteristics. A p level of $5 \%$ was accepted as statistically significant and calculations were made using SPSS.

\section{RESULTS}

The serum TAS, TOS, OSI, $80 \mathrm{HdG}$ and glucose values of all groups have been displayed in Table I.

While the serum TOS values $(\mathrm{p}<0.05)$ and the OSI values $(p<0.001)$ of the rats in diabetes group were found to be statistically significantly higher than those of the other groups, these values were found to be close to the control group in the rats in the Diabetes + wheatgrass group. However, the TAS values were determined to be higher in the wheatgrass group $(\mathrm{p}<0.05)$. The serum $80 \mathrm{HdG}$ level was higher in Diabetes group; however, the difference was statistically insignificant. While the serum glucose value was very high in the Diabetes group, it was seen to decrease in the wheatgrass + Diabetes group (Table I).

Taking the control group into consideration, the beta cells in the endocrine islands were examined immunehistochemically (Fig. 1A). The beta cells in the wheatgrass group were found to have a distribution close to that of the control group (Fig. 1B). The beta cells were seen to decrease in the diabetic group according to blood glucose levels (Fig. 1C). The beta cells were seen to increase in the group receiving wheatgrass for therapeutic purposes (Fig. 1D).

Table I. The values of serum glucose TAS-TOS-OSI $80 \mathrm{HdG}$ in all groups.

\begin{tabular}{lccccc}
\hline Parameters & Control & Wheatgrass & Diabetes & Wheatgrass+Diabetes & P value \\
\hline $8 \mathrm{OHdG}$ & $12.47 \pm 5.45$ & $15.22 \pm 3.51$ & $16.45 \pm 3.65$ & $14.29 \pm 4.23$ & $\geq 0.5$ \\
TAS & $0.55 \pm 0.26^{\mathrm{b}}$ & $0.98 \pm 0.35^{\mathrm{a}}$ & $0.47 \pm 0.43^{\mathrm{b}}$ & $0.68 \pm 0.19 \mathrm{a}$ & $\leq 0.5$ \\
TOS & $7.25 \pm 1.46^{\mathrm{b}}$ & $5.41 \pm 1.24 \mathrm{~b}$ & $9.11 \pm 1.82^{\mathrm{a}}$ & $6.15 \pm 1.35 \mathrm{~b}$ & $\leq 0.5$ \\
OS & $1.31 \pm 0.55^{\mathrm{b}}$ & $0.55 \pm 0.36^{\mathrm{c}}$ & $1.93 \pm 0.41^{\mathrm{a}}$ & $1.04 \pm 0.70 \mathrm{~b}$ & $\leq 0.01$ \\
Glucose & $81.15 \pm 4.26 \mathrm{c}$ & $87.34 \pm 9.46 \mathrm{c}$ & $475.20 \pm 72.36^{\mathrm{a}}$ & $250.00 \pm 48.25 \mathrm{~b}$ & $\leq 0.001$ \\
\hline
\end{tabular}

a,b,c: in the same line values with different letters show statistically significant differences. 
Table II. Semi-quantitative assessment of staining grades according to the groups.

$\begin{array}{cccc}\text { Konrol group } & \text { Wheatgrass group } & \text { Diabetes group } & \text { Diabetes+Wheatgrass Group } \\ (++++) & (++) /(+++) & (-) /(+) & (+) /(++)\end{array}$

$(++) /(+++)$

$(-) /(+)$ $(+) /(++)$
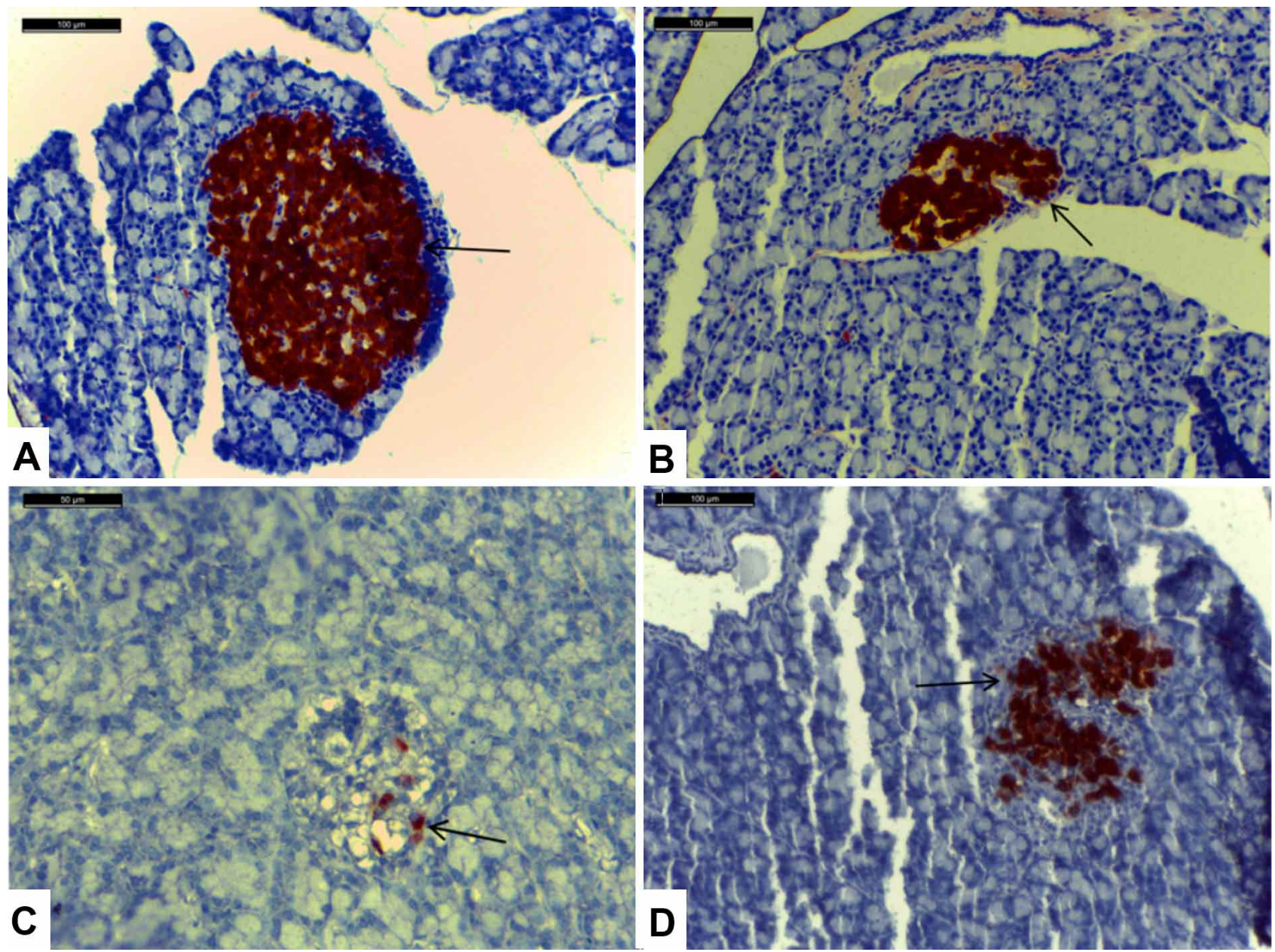

Fig.1. (A) Control, (B) Wheatgras, (C) Diabetes, (D) Diabetes+Wheatgrass (A, B, D Bar 100 $\mu \mathrm{m}$, C, Bar $50 \mu \mathrm{m}$ ).

\section{DISCUSSION}

Wheatgrass is recommended as supportive therapy in various diseases such as digestive problems, asthma, hypertension, thalassemia, diabetes, Parkinson's, ulcer, bronchitis, eczema and cancer (Singh et al., 2012; Ashish et al.; Durairaj et al., 2014). It is believed to strengthen the immune system and prolong the lifespan of cancer patients by suppressing the invasion of cancer cells (Durairaj et al.). Durairaj et al. found that wheatgrass extract was rich in alkaloids, mainly gamma sitosterol, squalene, cariofilene and amyrin, flavonoids, saponine, tannins, coumarin, phenols, alkaloids and terpenoids. Chlorophyll, which is one of the active components of wheatgrass extract, inhibits the metabolic activation of carcinogens (Kulkarni et al., 2006).

Researches have revealed that anti-oxidants prevent cell damage by neutralizing free radicals. Free radicals are suggested to be the main cause of atherosclerosis and cardiac diseases. Free radicals also affect the nucleic acids of free radicals. Excessive cell death leads to early aging and form cell sequences that lead to cancer and other diseases (Floyd, 1990) Free radical formation, which initiates some life-threatening chronic diseases as a result of oxidation, has increased the importance of anti-oxidant 
compounds that work against them. Cytotoxic aldehydes formed as a result of lipid peroxidation lead to injury through binding to proteins and DNA (Simic, 1994).

Previous studies have reported decreased glutathione reductase, serum glutathione peroxidase and catalase activity in DM (Komosinska-Vassev et al., 2005).

Kutlu et al. (2005) reported that vitamin E and C supplementation reduced lipid peroxidation in diabetic rats. Another study reported that $800 \mathrm{IU} /$ day vitamin E supplementation given for one month reduced all lipids and lipid fractions, the fasting plasma glucose and the fructosamine levels, TBARS levels, and increased insulin and $\mathrm{C}$ peptide levels, glutathione peroxidase and SOD activities; vitamin $\mathrm{E}$ is particularly beneficial in the prevention and treatment of type 2 Diabetes (Gökkusu et al., 2001).

Many methods and medications are currently used for management of Diabetes. They act through different mechanisms by increasing the insulin production or reducing the glucose production, minimizing the insulin resistance in related cell receptors and thereby aim at balancing the glucose homeostasis (Baxter, 2008).

Use of anti-oxidant substances or anti-diabetics with anti-oxidant properties is recommended to overcome oxidative stress (Memisogullari, 2005).

In their study investigating the anti-proliferative, apoptotic ad anti-oxidant activities of wheatgrass extract in CML (K562) cell series, Aydos et al. (2011) determined that the most apoptotic and anti-proliferative effect was seen in cell sequences treated with the water extract of wheatgrass at the 48th hour and that the MDA level, CAT and SOD activities increased $(\mathrm{p}<0.001)$. Wheatgrass extract has anti-oxidant activity and has been reported to inhibit the proliferation of leukemia cells and induce apoptosis.

Karadag et al. (2007) investigated the effects of wheatgrass on CML cells. They stated that apoptosis decreased due to the decrease in ROS in the cells treated with wheatgrass. Wheatgrass was determined to increase anti-oxidant enzymes, SOD and CAT.

Similar to with many previous studies, we determined higher serum TOS and OSI levels in rats in the Diabetes group. These values were found to be close to those of the control group in rats in the Diabetes + wheatgrass group. However, the TAS values in the wheatgrass group were found to be higher than those in the other groups.
Many researchers have shown that oxidative stress leads to DNA damage as a result of experimental diabetes and in vitro studies. As an indicator of oxidative damage, $8 \mathrm{OHdG}$ increases in tissues and body fluids in diabetic subjects (Park et al., 2001; Andican \& Burçak, 2005). Another study has revealed that lycopene, which has anti-oxidant effects, shows a DNA protective effect through inhibiting comet formation and reducing the $8 \mathrm{OHdG}$ level (Huang \& $\mathrm{Hu}, 2011$ ). On the other hand, wheatgrass is also effective in suppression of superoxide radicals, which cause many diseases beside the oxidative DNA-damage-protective effects (Falcioni et al., 2002).

In the present study, the serum $80 \mathrm{HdG}$ level was higher in the Diabetes group compared to the other groups; however, the difference was not statistically significant.

Drinking wheatgrass water was reported to reduce the need for blood-producing drugs and to help them reach healthy blood values (Bar-Sela et al., 2007). Another study reported that the use of wheatgrass water significantly reduced the general disease activity and rectal hemorrhage severity in the treatment of active distal ulcerative colitis (Ben-Arye et al., 2002).

The fresh juice of triticum aestivum leaves administered via the per-oral route showed a significant hypolipidemic effect in normal mice (Kothari et al., 2008). Mohan et al. (2013) reported that wheatgrass extract demonstrated significant anti-hyperglycemic, hypo-lipidemic and antioxidant activity in diabetic rats induced with streptozotocin. Rana et al. reported that wheatgrass was effective in removing toxins, balancing plasma glucose, preventing tooth decay, maintaining healthy hair and reducing high blood pressure. In the present study, while the serum glucose level was very high in the Diabetes group, it decreased in the wheatgrass + Diabetes group, consistent with these studies.

STZ-induced degeneration in pancreatic beta-cells was determined immune-histochemically. It was concluded that wheatgrass increased the free radical amount and could protect the beta cells against beta cell damage in the wheatgrass + Diabetes group. This result is similar to the study of Karaca $e t$ al.(2010) investigating the protective effect of ginseng, green tea and green tea + ginseng in STZ-induced diabetic rats.

\section{CONCLUSION}

Diabetes is a metabolic disease, which has a gradually increasing prevalence. Many mechanisms have been suggested in the pathogenesis of diabetes and its 
complications. Among these, the most accepted mechanism is regarding the free radicals. Diabetes-induced oxidative stress may be overcome by increasing the anti-oxidant capacity. The number of studies on anti-oxidants and the effects on diabetes is increasing day by day. There are studies on the protective and therapeutic effect of wheatgrass in cancer; however, there is a limited number of studies regarding the effects of wheatgrass on diabetes. In this study, we determined that wheatgrass strengthened the anti-oxidant defense system and reduced the glucose level in diabetic rats. Wheatgrass may contribute to diabetes management through reduction in oxidative stress and prevention of diabetic complications. Therefore, we recommend wheatgrass to overcome oxidative stress in diabetes. We suggest that wheatgrass would also be beneficial due to its anti-hyperglycemic effect.

MIS, L.; COMBA, B.; USLU, S. \& YELTEKIN, A. Efecto del pasto de trigo sobre el daño del ADN, el índice de estrés oxidativo y los hallazgos histológicos en ratas diabéticas. Int. J. Morphol., 36(4):1235-1240, 2018.

RESUMEN: El objetivo de este estudio fue buscar el efecto del pasto de trigo sobre el estado total de antioxidantes (TAS) -Oxidan Status (TOS) y el daño del ADN en ratas con diabetes. Las ratas analizadas en el estudio se dividieron aleatoriamente en 4 grupos de 10 ejemplares cada uno: grupo control; $1 \mathrm{ml}$ de tampón fosfato-citrato de dosis única inyectado i.p.(pH: 4,5)., Grupo diabetes; $45 \mathrm{mg} / \mathrm{kg}$ de estreptozotocina en dosis única inyectada i.p., grupo pasto de trigo; se administró pasto de trigo oral $(10 \mathrm{ml} / \mathrm{kg} /$ día $)$ durante 6 semanas, grupo diabetes + pasto de trigo; $45 \mathrm{mg} / \mathrm{kg}$ de estreptozotocina en dosis única inyectada i.p. y pasto de trigo $(10 \mathrm{ml} / \mathrm{kg} /$ día $)$ por vía oral durante 6 semanas. Después del proceso experimental durante 6 semanas, se tomaron muestras de sangre y tejido de páncreas. Se midieron los niveles de glucosa en sangre, TAS, y TOS mediante kits colorimétricos; El daño al ADN fue realizado por kits de ELISA en suero. Los tejidos del páncreas se examinaron histopatológicamente. En el grupo de diabetes + pasto de trigo se determinó que los niveles de glucosa $(\mathrm{p}<0,001)$, TOS $(\mathrm{p}<0,05)$ y OSI $(\mathrm{p}<0,01)$ disminuyeron estadísticamente y curaron histopatológicamente en comparación con el grupo de diabetes. En el grupo de pasto de trigo se determinó que los niveles de TAS p $<0,05$ se incrementaron estadísticamente con respecto a otros grupos. No fue estadísticamente significativo el nivel de las diferencias séricas de $8 \mathrm{OHdG}$ entre los grupos. Se observó que las células beta aumentaron en el grupo que recibió pasto de trigo con fines terapéuticos. Como conclusión, se determinó que el pasto de trigo fortaleció el sistema de defensa antioxidante y redujo el nivel de glucosa en las ratas diabéticas.

PALABRAS CLAVE: Pasto de trigo; Diabetes; Daño en el ADN; TAS; Célula beta.

\section{REFERENCES}

Akcay, G. \& Akarsu, E. Endocrine and Metabolic Diseases. Erzurum, Aktif Publishing, 2000

Andican, G. \& Burçak, G. Oxidative damage to nuclear DNA in streptozotocin-diabetic rat liver. Clin. Exp. Pharmacol. Physiol., 32(8):663-6, 2005.

Ashish, S.; Shilpa, K.; Singh, R. R.; Sanjay, K. \& Rajendran, N. Wheatgrass: An alternative household nutritional food security. Int.Res.J. Pharm., 3(7):246-50, 2012.

Aydos, S. E.; Avci, A.; Ozkan, T.; Karadag, A.; Gürleyik, E.; Altinok, B. \& Sungurolu, A. Antiproliferative, apoptotic and antioxidant activities of wheatgrass (Triticum aestivum L.) extract on CML (K562) cell line. Turk. J. Med.Sci., 41(4):657-63, 2011.

Bar-Sela, G.; Tsalic, M.; Fried, G. \& Goldberg, H. Wheat grass juice may improve hematological toxicity related to chemotherapy in breast cancer patients: a pilot study. Nutr. Cancer, 58(1):43-8, 2007.

Baxter, M. Treatment of type 2 diabetes: a structured management plan. Adv. Ther., 25(2):106-14, 2008.

Ben-Arye, E.; Goldin, E.; Wengrower, D.; Stamper, A.; Kohn, R. \& Berry, E. Wheat grass juice in the treatment of active distal ulcerative colitis: a randomized double-blind placebo-controlled trial. Scand. J. Gastroenterol., 37(4):444-9, 2002.

Durairaj, V.; Hoda, M.; Shakya, G.; Babu, S. P. \& Rajagopalan, R. Phytochemical screening and analysis of antioxidant properties of aqueous extract of wheatgrass. Asian Pac. J. Trop. Med., 7S1:S398404, 2014.

Falcioni, G.; Fedeli, D.; Tiano L.; Calzuola, I.; Mancinelli, L.; Marsili, V. \& Gianfranceschi, G. Antioxidant activity of wheat sprouts extract in vitro: inhibition of DNA oxidative damage. J. Food Sci., 67(8):291822, 2002.

Floyd, R. A. Role of oxygen free radicals in carcinogenesis and brain ischemia. FASEB J., 4(9):2587-97, 1990

Gökkusu, C.; Palanduz, S.; Ademoglu, E. \& Tamer, S. Oxidant and antioxidant systems in niddm patients: influence of vitamin $\mathrm{E}$ supplementation. Endocr. Res., 27(3):377-86, 2001.

Gorogawa, Si.; Kajimoto, Y.; Umayahara, Y.; Kaneto, H.; Watada, H.; Kuroda,A.; Kawamori, D.; Yasuda, T.; Matsuhisa, M.; Yamasaki, Y. \& Hori, M. Probucol preserves pancreatic beta-cell function through reduction of oxidative stress in type 2 diabetes. Diabetes Res. Clin. Pract., 57(1):1-10, 2002.

Huang, C. S. \& Hu, M. L. Lycopene inhibits DNA damage and reduces hMTH1 mRNA expression in the liver of Mongolian gerbils treated with ferric nitrilotriacetate. Food Chem. Toxicol., 49(6):1381-6, 2011.

Kanter, M.; Uysal, H.; Karaca, T. \& Sagmanligil, H. O. Depression of glucose levels and partial restoration of pancreatic beta-cell damage by melatonin in streptozotocin-induced diabetic rats. Arch. Toxicol., 80(6):362-9, 2006.

Karaca, T.; Yoruk, M.; Yoruk, I. H. \& Uslu, S. Effects of extract of green tea and ginseng on pancreatic beta cells and levels of serum glucose, insulin, cholesterol and triglycerides in rats with experimentally streptozotocin-induced diabetes: A histochemical and immunohistochemical study. J. Anim. Vet. Adv., 9(1):102-7, 2010.

Karadag, A.; Ozkan, T.; Altinok, B.; Aydos, S. \& Sunguroglu, A. Antiproliferative and apoptotic effects of wheatgrass (Triticum aestivum L.) extracts on chronic myeloid leukemia (CML) cell line. Planta Med., 73:P_540, 2007.

Komosinska-Vassev, K.; Olczyk, K.; Olczyk, P. \& Winsz-Szczotka, K. Effects of metabolic control and vascular complications on indices of oxidative stress in type 2 diabetic patients. Diabetes Res. Clin. Pract., 68: 207-16, 2005.

Kothari, S.; Jain, A. K.; Mehta, S. C. \& Tonpay, S. D. Effect of fresh Triticum aestivum grass juice on lipid profile of normal rats. Indian J.Pharmacol., 40(5):235-6, 2008. 
Kulkarni, S. D.; Tilak, J. C.; Acharya, R.; Rajurkar, N. S.; Devasagayam, T.P. \& Reddy,A. V. Evaluation of the antioxidant activity of wheatgrass (Triticum aestivum L.) as a function of growth under different conditions. Phytother. Res., 20(3):218-27, 2006.

Kutlu, M.; Naziroglu, M.; Sims, ek, H.; Yilmaz, T. \& Sahap Kükner, A. Moderate exercise combined with dietary vitamins $\mathrm{C}$ and $\mathrm{E}$ counteracts oxidative stress in the kidney and lens of streptozotocin-induced diabetic-rat. Int. J. Vitam. Nutr. Res., 75(1):71-80, 2005.

Memis, ogullari, R. Diyabette Serbest Radikallerin Rolü ve Antioksidanların Etkisi. Düzce Tip Fakültesi Dergisi, 3:30-9, 2005.

Mohan, Y.; Jesuthankaraj, G. N. \& Thangavelu, N. R. Antidiabetic and antioxidant properties of Triticum aestivum in streptozotocin-induced diabetic rats. Adv. Pharm. Sci., 2013:716073, 2013.

Park, K. S.; Kim, J. H.; Kim, M. S.; Kim, J. M.; Kim, S. K.; Choi, J. Y.; Chung, M. H.; Han, B.; Kim, S. Y. \& Lee, H. K. Effects of insulin and antioxidant on plasma 8-hydroxyguanine and tissue 8hydroxydeoxyguanosine in streptozotocin-induced diabetic rats. Diabetes, 50(12):2837-41, 2001.

Piconi, L.; Quagliaro, L. \& Ceriello, A. Oxidative stress in diabetes. Clin. Chem. Lab.Med., 41(9):1144-9, 2003.

Rana, S.; Kamboj, J. K. \& Gandhi, V. Living life the natural way Wheatgrass and health. Func. Foods Health Dis., 1(11):444-56, 2011.

Simic, M. G. DNA markers of oxidative processes in vivo: relevance to carcinogenesis and anticarcinogenesis. Cancer Res., 54(7 Suppl.):1918s23s, 1994

Singh, N.; Verma, P. \& Pandey, B. R. Therapeutic potential of organic Triticum aestivum linn. (Wheat Grass) in prevention and treatment of chronic diseases: An overview. Int. J. Pharm. Sci. Drug Res., 4(1):104, 2012.

Vincent, A. M.; Russell, J. W.; Low, P. \& Feldman, E. L. Oxidative stress in the pathogenesis of diabetic neuropathy. Endocr. Rev., 25(4):612$28,2004$.
Corresponding author:

Leyla Mis

Department of Physiology

Faculty of Veterinary Medicine

Yuzuncu Yil University

TR-65090 Van

TURKEY

Email: leylaaslan23@hotmail.com

Received: 27-03-2018

Accepted: 06-08-2018 